JURNAL SYNTAX FUSION

Vol 1 No 11, November 2021

E-ISSN: 2775-6440 | P-ISSN: 2808-7208

Jurnal Homepage https://fusion.rifainstitute.com

\title{
PENERAPAN HUKUMAN MATI TERHADAP NARAPIDANA LANJUT USIA DITINJAU DARI HAK ASASI MANUSIA
}

\section{Fitrian Romadhon Dwi Saputra, Mitro Subroto}

Politeknik Ilmu Pemasyarakatan, Indonesia

Email: Fitrianromadhon28@gmail.com,mitro.suroto@gmail.com

\section{Abstract}

Law as a tool to change society or social engineering. Indonesia as a State of Law with Positive Law, namely the Criminal Code still imposes criminal sanctions in the form of the death penalty. In essence, the death penalty is a punishment by eliminating the life of the convict. However, the application of the death penalty creates a causa celebre (trigger) for the re-emergence of polemics against the pros and cons of the death penalty decision. This is especially true for elderly prisoners. Because there are provisions regulated in Law No. 13 of 1998 concerning Elderly Welfare which discusses the rights of elderly convicts. Then from the perspective of human rights, the death penalty is not inconsistent with national or international legal instruments, such as the 1945 Constitution, Law No. $39 / 1999$ on Human Rights, the 1948 Universal Declaration on Human Rights, and the International Covenant on Civil Rights. and Political Rights 1966. The method used in this paper is normative juridical and analytical descriptive.

Keywords: Human Rights Perspective, normative juridical, and analytical descriptive.

\begin{abstract}
Abstrak
Hukum adalah media dalam merubah masyarakat dan bisa juga disebut rekayasa sosial. Indonesia sebagai Negara Hukum dengan Hukum Positif, yaitu Kitab Undangundang Hukum Pidana (KUHP) masih memberlakukan sanksi pidana berupa Pidana mati. Hakikatnya pidana mati adalah hukuman dengan menghilangkan nyawa terpidana. Namun penerapan pidana mati menimbulkan causa celebre (pemicu) munculnya kembali polemik terhadap pro dan kontra pada putusan pidana mati. Khususnya dilakukan kepada narapidana yang telah lanjut usia. Sebab ada ketentuan yang diatur dalam Undang-Undang Nomor 13 Tahun 1998 tentang Kesejahteraan Lanjut Usia yang membahas mengenai hak-hak dari terpidana yang telah lanjut usia. Lalu pada sudut pandang hak asasi manusia, hukuman mati tidak bertentangan dengan sumber hukum-hukum nasional maupun internasional, misal Undang-undang Dasar 1945, Undang-undang Nomor 39 Tahun 1999 tentang Hak Asasi Manusia, Universal Declaration on Human Rights 1948, maupun International Covenant on
\end{abstract}


Civil and Political Rights 1966. Metode yang digunakan dalam penulisan ini adalah yuridis normatif dan deskriptif analitis.

Kata kunci: Sudut Pandang Hak Asasi Manusia, yuridis normatif, dan deskriptif analitis

Diterima: 23-10-2021 Direvisi: 12-11-2021_Diterbitkan: 20-11-2021

\section{Pendahuluan}

Penegakan hukum adalah proses dalam upaya penegakan atau keberfungsian normanorma hukum secara riil yang menjadi penuntun perilaku dalam ikhwal ketertiban dalam transportasi maupun pada sosial kemasyarakatan dan negara. Dilihat dari sudut pandang subjektif, penegakan hukum bisa dilaksanakan oleh subjek yang cakupan nya universal serta bisa diartikulasikan sebagai upaya penegakan hukum itu membutuhkan keterlibatan oleh seluruh subyek hukum pada tiap relasi hukum (Wahyuni, 2020).

Sejalan dengan itu, Indonesia sebagai Negara Hukum di dalam Hukum Positif, yaitu Kitab Undang-undang Hukum Pidana masih memberlakukan sanksi pidana berupa Pidana mati. Ditinjau perjalanan historis awal mula adanya opini yang pro dan kontra terhadap pidana mati, masing-masing dibekali dengan argumen yang akuntabel secara yuridis. Tokohtokoh pada masa lampau yang diketahui kontra terhadap adanya putusan pidana mati yaitu penyair Jerman Lessing, Klopstock, Moser dan Achillec, Beccaria, Voltaire, Marat dan Robespiere. Sedangkan tokoh-tokoh yang pro terhadap pidana mati yakni, Otto von Bismarck, De Savornin Lohman, Garovalo, Lombroso, Rambonnet, serta Bichon Van Yuclmonde Ysselmonde (Saleh, 1978).

Disisi lain penerapan pidana mati menimbulkan causa celebre (pemicu) munculnya kembali polemik terhadap pro dan kontra pada putusan pidana mati dalam hukum pidana positif di Indonesia. Dalam KUHP atau Kitab Undang-Undang Hukum Pidana Indonesia turut membatasi kemungkinan sebuah putusan hukuman mati kepada kejahatan-kejahatan yang berat seperti kejahatan terhadap pertahanan dan keamanan negara yang termaktub pada Pasal 104, Pasal 111 ayat 2, Pasal 124 ayat 3, dan Pasal 140 ayat 3), pembunuhan yang direncanakan (Pasal 340), pencurian yang dilakukan dengan tindakan kekerasan sehingga menyebabkan luka yang berat atau kematian (Pasal 365 ayat 4), pemerasan dengan kekerasan yang dilakukan mengakibatkan luka yang berat atau kematian (Pasal 368 ayat 2) dan perampokan di pesisir dan pantai (Pasal 44 KUHP) (Ohoiwutun, Nugroho, Nanda, \& Manek, 2019).

Lalu regulasi hukuman pidana mati diluar KUHP meliputi, UU No. 31 Tahun 1999 mengenai Tipikor sebagaimana telah diubah dan ditambah dengan UU No. 20 Tahun 2001 Pasal 2 ayat (2), UU No. 35 Tahun 2009 mengenai Tindakan Pidana Narkotika, dalam Pasal 113, 114, 118, 119, 121, lalu Pasal 44, UU No. 21 (Prp) Th. 1959 mengenai pemberatan Ancaman Hukuman Tindak Pidana Ekonomi, Pasal 2 dalam UU No. 15 tahun 2003 tentang penetapan peraturan pemerintah pengganti UU No. 1 tahun 2002 tentang pemberantasan 
terorisme, yang kemudian menjadi UU juncto. PP (Peraturan Pemerintah) pengganti UU Republik Indonesia No. 1 Tahun 2002 tentang Pemberantasan Terorisme. Pada Pasal 6, 8, 10, 14, 15, 16, UU No. 26 Tahun 2000 mengenai Pengadilan HAM, Pasal 36, Pasal 37, Pasal 41.

Sedangkan di UUD 1945 menurut Mahkamah Konstitusi (MK) tidak adanya hukuman Pidana Mati. Mahkamah Konstitusi (MK) mengacu pada keaslian intent pembentuk UUD Negara Republik Indonesia 1945 yang menyatakan bahwa HAM bisa dibatasi. Hal tersebut juga diperjelas dengan Pasal 28 J ayat (1) dan (2) UUD Negara Republik Indonesia 1945 yang menyatakan: "(1) Setiap orang wajib menghormati hak asasi manusia orang lain dalam tertib kehidupan bermasyarakat, berbangsa, dan bernegara. (2) Dalam menjalankan hak dan kebebasannya, setiap orang wajib tunduk kepada pembatasan yang ditetapkan dengan undang-undang dengan maksud semata-mata untuk menjamin pengakuan serta penghormatan atas hak dan kebebasan orang lain dan untuk memenuhi tuntutan yang adil sesuai dengan pertimbangan moral, nilai-nilai agama, keamanan, dan ketertiban umum dalam suatu masyarakat demokratis." Maka, secara tafsiran tersistematis (sistematische interpretatie), HAM yang diatur dalam Pasal 28A sampai Pasal 28 I UUD 1945 patuh terhadap pembatasan HAM yang diatur dalam Pasal 28 J ayat (2) UUD 1945 (Eleanora, 2012).

Peniadaan hukuman mati sudah banyak digagas oleh banyak pihak, salah satunya dari ICCPR atau International Covenant on Civil and Political Rights. Konsepsi ICCPR sendiri mengakui adanya hak hidup setiap individu yang tidak bisa dikurangi sebagaimana tertulis pada Pasal 6 Ayat (1) ICCPR. Rumusan tersebut banyak dipakai oleh pemohon untuk mendukung pendapatnya ke Mahkamah Konstitusi. Pendapat yang paling umum dipakai ialah berbunyi "Tidaklah melarang negara-negara pihak (state parties) untuk memberlakukan pidana mati, tetapi ada pembatasan diberlakukan hanya terhadap kejahatankejahatan yang paling mengkhawatirkan yang disesuaikan pada aturan yang sah pada saat adanya kejahatan tersebut".

Indonesia secara normatif konstitusional adalah negara hukum yang memiliki tanggung jawab kepada seluruh warga negaranya tanpa terkecuali termasuk kepada para warga negara lanjut usia (lansia), walaupun pada dasarnya lanjut usia (atau sering disingkat lansia) merupakan periode kemunduran yang sebagian disebabkan dari fisik dan psikologis. Kemunduran bisa berdampak pada psikologis lansia dan motivasi merupakan peran yang penting dalam kemunduran terhadap lansia. Dalam hubungan pada masalah kemunduran itu menurut Elizabeth B. Hurlock dalam Argyo Demartoto (2006) mengatakan kalau orang yang mengalami kemunduran tersebut diperkirakan dimulai saat memasuki umur 60 tahun yang dicirikan dengan adanya transformasi fisik dan psikologis yang mengarah dengan kesesuaian pribadi yang tidak baik dan kehidupanya menjadi tidak bahagia (Hakim, Kartono, \& Demartoto, n.d.). 
Sulit untuk membayangkannya bagaimana jika dalam masa kemunduran karena faktor lanjut usia harus berurusan dengan hukum karena diduga melakukan suatu perbuatan hukum. Secara normatif setiap orang/ masyarakat yang melakukan pelanggaran hukum pidana atau lebih dikenal dengan tindak pidana, maka yang bersangkutan harus bertanggungjawab atas perbuatan hukum yang dilakukannya.

Dalam Undang-Undang No. 13 Th 1998 mengenai Kesejahteraan Lanjut Usia definisi dari lansia yaitu seseorang lelaki ataupun seorang wanita yang berumur 60 tahun atau lebih atau seorang yang telah mencapai usia 60 tahun keatas dimana kemampuan fisik dan kognitifnya mengalami penurunan.

Namun sebagai Negara Hukum (Pasal 1 ayat 3) Indonesia, tetap terikat dan berpedoman kepada aturan-aturan tertulis dalam bentuk undang-undang dan peraturan pelaksanaannya. Tahapan penyelesaian atau penegakan hukum (law enforcement) kepada tiap tindak pidana, wajib diselesaikan pada tata cara sistem peradilan pidana, yang berarti tiap pelaku tindak pidana baik itu anak-anak, orang dewasa atau termasuk golongan lanjut usia.

Berdasarkan permasalahan yang terjadi terhadap penerapan hukuman mati kepada narapidana lanjut usia yang dikaji dari hak asasi manusia dapat menunjukkan bahwa sistem hukum di Indonesia masih harus banyak diperbaiki agar menciptakan sistem tatanan masyarakat yang madani. Berdasarkan permasalahan diatas, peneliti juga mengharapkan penting adanya edukasi terkait penerapan hukuman mati pada narapidana apabila dikaji dari hak asasi manusia sehingga akan bermanfaat untuk kemudian hari bagi Warga Binaan dan keluarga.

\section{Metode Penelitian}

Studi ini menggunakan metode yuridis normatif yakni metode pendekatan kegiatan yang menjelaskan secara yuridis tanpa memerlukan dukungan data atau fakta-fakta sosial, karena dalam mendeskripsikannya hanya mencari makna dan memberi nilai akan hukum serta bentuk penyelesaiannya memakai langka-langkah yang normatif (Soemitro, 1990).

Proses dalam pengumpulan data menggunakan cara observasi dengan mengeksplorasi data sekunder yaitu data yang diperoleh dari literatur dan bahan kepustakaan yang berkaitan dengan topik permasalahan mengenai adanya hukuman mati pada terpidana yang telah lanjut usia dari sudut pandang hak asasi manusia.

Dalam pengidentifikasian faktor-faktor dan penyebab terjadinya permasalahan kemudian dalam memudahkan hal pengolahan data yang dapat mudah dimengerti diperlukan spesifikasi yang digunakan dalam penulisan ini, yaitu deskriptif analitis. Karena dalam penelitian ini menggambarkan atau memvisualisasikan dari perspektif hak asasi manusia yang diserap dari literatur maupun aturan yang berlaku (Peraturan dan perundang-undangan) terhadap sanksi pidana mati bagi narapidana yang telah lanjut usia (Rukajat, 2018). 


\section{Hasil dan Pembahasan}

Hukum merupakan media dalam merubah masyarakat atau rekayasa sosial tidak lain hanya merupakan ide-ide yang ingin diwujudkan oleh hukum itu. Dalam menjamin tercapainya fungsi hukum sebagai rekayasa masyarakat kearah yang lebih baik, maka bukan hanya dibutuhkan ketersediaan hukum dalam arti kaidah atau peraturan, melainkan juga adanya jaminan atas perwujudan kaidah hukum tersebut ke dalam praktek hukum, atau dengan kata lain, jaminan akan adanya penegakan hukum (law enforcement) yang baik.

Pidana mati merupakan hukuman yang berat dan sudah dikenal sejak lama dan hingga sekarang masih diberlakukan di berbagai negara termasuk Indonesia. Indonesia sendiri masih mengakui sanksi pidana mati. Banyak tindak pidana yang dilakukan oleh pelaku tindak pidana yang diancam dengan pidana mati. Didalam Kitab Undang-Undang Hukum Pidana terdapat sistem hukuman pidana mati yang dianut di Indonesia.

Berdasarkan hasil pengamatan tentang sanksi pidana mati bagi narapidana diketahui bahwa Pemerintah Indonesia telah mengeksekusi 66 orang para terpidana matinya dalam kurun waktu 1979-2015 (Kelik Wardiono, Natangsa Surbakti, Rachma, \& SH, 2020). Berikut data yang menampilkan beberapa kasus terpidana mati yang telah dieksekusi di periode 2008-2015.

Tabel 1. Daftar Terpidana Mati yang telah di Eksekusi periode 2008 - 2015.

\begin{tabular}{cccc}
\hline No & Nama & Kasus & $\begin{array}{c}\text { Tahun di } \\
\text { Eksekusi }\end{array}$ \\
\hline 1. & Sumiarsih & Pembunuhan Berencana & 2008 \\
\hline 2. & Ahmad Suradji & Pembunuhan Berencana & 2008 \\
\hline 3. & Imam Samudra & Pengeboman & 2008 \\
\hline 4. & Amrozi & Pengeboman & 2008 \\
\hline 5. & Muhklas & Pengeboman & 2008 \\
\hline 6. & Rio Alex Bullo & Pembunuhan Berencana & 2008 \\
\hline 7. & Rani Andriani & Narkoba & 2015 \\
\hline 8. & Namaona Denis & Narkoba & 2015 \\
\hline 9. & Ang Kim Soe & Narkoba & 2015 \\
\hline
\end{tabular}

(Sumber: Tempo, 2019)

Berdasarkan data diatas dapat disimpulkan jika penerapan hukuman mati bagi narapidana Indonesia tergolong tinggi. Apabila dilihat dari aturan dan regulasi yang berlaku ikhwal tentang pidana mati bagi narapidananya terdapat pada Kitab Undang-Undang Hukum Pidana atau diluar KUHP. Menelisik di KUHP pasal-pasal yang mengarah kepada sanksi pidana mati antara lain: 
1. Pasal 104 KUHP (Makar dan pembunuhan Presiden), menurut Moeljanto maksud makar dari pasal ini adalah menekankan pada sikap tindakan yang dilakukan dengan tujuan untuk menyerang atau membunuh seseorang dalam rangka menjatuhkan Pemerintahan yang sah pada waktu itu (Moeljatno, 2021). Saat melakukan makar tidak harus ada perencanaan terlebih dahulu, cukup apabila unsur kesengajaan maka pelaku sudah bisa dijerat di dalam Pasal ini, sebab hal tersebut telah diatur pada Pasal 87 KUHP yang disebut ada makar saat melakukan suatu perbuatan, jika niat untuk itu telah ternyata dari adanya permulaan pelaksanaan, seperti dimaksud dalam Pasal 53 (Susilo, 1995).

2. Pasal 111 Ayat (2) KUHP (Mengajak Negara asing guna menyerang Indonesia dalam perang), menurut Moeljanto maksud dari Pasal ini adalah adanya ajakan untuk melakukan hubungan kerjasama dengan pihak lain (negara asing, suku bangsa, pimpinan suatu bangsa, atau korporasi) untuk melakukan tindakan yang bermusuhan atau berperang dengan negaranya, maka yang bersangkutan dapat dipidana mati jika permusuhan atau perang tersebut sungguh terjadi (Moeljatno, 2021).

3. Pasal 124 Ayat (3) KUHP (Memberi pertolongan kepada musuh waktu Indonesia dalam perang) maksud dari Pasal ini adalah tentang kondisi keadaan perang jika negara dalam situasi perang dengan musuh dimana keadaan saat perang tersebut terdapat pihak yang dengan sengaja menyebabkan negara dirugikan akibat perbuatan tersebut karena telah memberikan bantuan kepada musuh.

4. Pasal 140 Ayat (3) KUHP (Pembunuhan dengan direncanakan lebih dahulu) maksud dari Pasal 140 Ayat (3) KUHP berhubungan dengan Pasal 104 KUHP, yakni Makar terhadap Kepala Negara tetapi Pasal 140 Ayat (3) KUHP dimaksudkan pada Kepala Negara sahabat atau yang memerintah, pemberian hukuman mati atau penjara seumur hidup atau selama waktu tertentu dimana hukuman paling lama dua puluh tahun, dalam kondisi tindakan yang telah direncanakan sehingga mengakibatkan kematian pada Kepala Negara sahabat atau yang memerintah.

5. Pasal 340 KUHP (Pembunuhan berencana) Pembunuhan berencana (340 KUHP) mengandung keseluruhan unsur pembunuhan pokok (338 KUHP) serta satu unsur tambahan, yaitu dengan rencana terlebih dahulu. Bisa dibilang jika pembunuhan yang dimaksud oleh Pasal 338 KUHP yakni tanpa rencana tetapi dalam Pasal 340 KUHP adalah dengan rencana terlebih dahulu.

6. Pasal 365 Ayat (4) KUHP (Pencurian dengan kekerasan) mengandung rumusan jika:

a. Pencurian yang dilakukan disertai dengan perbuatan hukum lainnya yang dapat dipidana.

b. Dilakukan dengan unsur kesengajaan. 
Penerapan Hukuman Mati Terhadap Narapidana Lanjut Usia Ditinjau Dari Hak Asasi

Manusia

c. Perbuatan dilakukan dengan maksud mempermudah atau mempersiapkan pelaksanaan pencurian.

d. Dilakukan dengan adanya tindakan kekerasan atau ancaman kekerasan.

e. Ataupun untuk melarikan diri atau mempertahankan isi kepemilikan dari barang yang telah dicurinya.

7. Pasal 44 KUHP (Pembajakan) maksud dari rumusan pasal tersebut adalah mengandung Pembajakan di Lautan yang Mengakibatkan Kematian Mengenai tindak pidana pembajakan baik yang dilakukan di laut, di pantai, di pesisir, dan di sungai apabila mengakibatkan kematian, diancam pidana sampai pada pidana mati.

Selanjutnya adalah pasal-pasal yang termaktub pada pengaturan yang mengatur adanya sanksi pidana mati diluar KUHP, yaitu:

1. Pasal 2 Ayat (2) Undang-Undang Nomor 31 Tahun 1999 tentang Tindak Pidana Korupsi sebagaimana telah diubah dan ditambah dengan UU No 20 Tahun 2001 yang berbunyi "Dalam hal tindak pidana korupsi sebagaimana dimaksud dalam Ayat (1) dilakukan dalam keadaan tertentu pidana mati dapat dijatuhkan”. Dapat diinformasikan dari rumusan pasal tersebut bahwa pidana mati dapat dijatuhkan jika ada pihak yang melakukan perbuatan memperkaya diri sendiri di saat negara sedang dalam keadaan berbahaya seperti perang, bencana alam nasional, atau saat krisis moneter atau ekonomi.

2. Pasal 36 dan Pasal 37 Undang-Undang Nomor 26 Tahun 2000 tentang Pengadilan Hak Asasi Manusia yang bermakna bahwa seseorang dapat diberikan hukuman mati jika telah terbukti melakukan kejahatan kemanusiaan berupa genosida dengan maksud menghancurkan atau memusnahkan seluruh atau sebagian kelompok bangsa, ras, kelompok etnis, kelompok agama.

3. Undang - Undang Nomor 35 Tahun 2009 tentang Tindak Pidana Narkotika yaitu pada Pasal 113 Ayat (2), Pasal 114 Ayat (2), Pasal 116 Ayat (2), Pasal 118 Ayat (2), 119 Ayat (2), Pasal 121 Ayat (2), serta Pasal 133 menyeluruh. Pada pasalpasal tersebut dapat disebutkan bahwa dapat dijatuhi hukuman mati kepada seseorang yang telah terbukti memproduksi, mengimpor, atau menyalurkan narkotika golongan I dan II, atau memperjualbelikan, membeli, sebagai perantara, atau memberikan kepada orang lain sehingga menyebabkan orang tersebut mengalami kematian atau kecacatan permanen pada fisik maupun mental.

4. Pasal 1 Ayat (2) Undang-Undang Nomor 21 Tahun 1959 Tentang Memperberat Ancaman Hukuman Tindak Pidana Ekonomi berarti bahwa delik ekonomi yang dilakukan dengan keadaan yang memperberat pidana yaitu, "dapat menimbulkan kekacauan di bidang perekonomian dalam masyarakat", dapat dipidana mati.

5. Undang- Undang Nomor 15 tahun 2003 tentang penetapan peraturan pemerintah pengganti Undang-Undang Nomor 1 tahun 2002 tentang pemberantasan tindak 
pidana terorisme, menjadi Undang -Undang juncto. Peraturan pemerintah pengganti Undang-Undang Republik Indonesia Nomor 1 Tahun 2002 tentang Pemberantasan Tindak Pidana Terorisme diatur Pasal 6, Pasal 8 dan Pasal 10.

Melihat dari literasi hukum yang ada di Indonesia klasifikasi tindakan pidana yang dapat dijatuhi hukuman mati merupakan tindakan yang berdampak sangat luas bagi kemaslahatan seluruh bangsa dan negara.

Mengingat dampak negatif yang sangat besar dari adanya sanksi pidana mati, tetapi pidana mati dianggap sebagai adanya keadilan dalam masyarakat. Namun di sisi lain, pidana mati juga dianggap sebagai pelanggaran terhadap hak asasi manusia, yaitu hak untuk hidup. Walaupun demikian, penjatuhan pidana mati masih dirasakan urgen terhadap pelaku tindak pidana yang sangat merugikan bagi masyarakat.

Pada hakikatnya pidana mati adalah hukuman dengan menghilangkan nyawa terpidana, oleh karenanya dengan menghilangkan nyawa pelaku tindak pidana tersebut berarti menghentikan pelaku untuk melanjutkan kejahatan kembali. Maka dengan adanya pidana mati, masyarakat dapat merasa aman dan terlindungi dari para pelaku atau terpidana tersebut. Jika dikaji dari unsur perlindungan masyarakat kebijakan sanksi hukuman mati kepada narapidana bisa dibilang memenuhi atau sesuai dengan aspek perlindungan masyarakat.

Dalam perspektif hak asasi manusia, pemberian hukuman mati terhadap narapidana masih menjadi perdebatan di banyak pihak. Sebagian pihak mempermasalahkan dari segi instrumen hukum, baik nasional maupun internasional yang mengatur mengenai hak asasi manusia. Beberapa instrumen hukum yang mengakui keberadaan hak asasi manusia terutama hak untuk hidup, antara lain adalah Undang-undang Dasar 1945, Undang-undang tentang Hak Asasi Manusia, Universal Declaration of Human Rights, dan International Covenant on Civil and Political Rights (ICCPR) (Sumanto, 2004).

Pada perspektif Undang-Undang Dasar 1945 secara khusus mengatur tentang hak asasi manusia dalam 3 (tiga) Pasal yakni Pasal 28A, Pasal 28I, dan Pasal 28J. Ketiga pasal tersebut meliputi:

a. Pasal 28A: Hak untuk hidup dan mempertahankan kehidupan;

b. Pasal 28I: (1) Hak untuk hidup, hak untuk tidak disiksa, hak kemerdekaan pikiran dan hati nurani, hak beragama, hak untuk tidak diperbudak, hak untuk diakui sebagai pribadi di hadapan hukum, dan hak untuk tidak dituntut atas dasar hukum yang berlaku dan hak asasi manusia yang tidak dapat dikurangi dalam keadaan apapun; dan

c. Pasal 28J: (1) setiap orang wajib menghormati hak asasi manusia orang lain dalam tertib kehidupan bermasyarakat, berbangsa, dan bernegara; (2) Dalam menjalankan dan melindungi hak asasi manusia dan kebebasannya, setiap orang wajib tunduk kepada pembatasan yang diterapkan dengan undang-undang dengan maksud semata-mata untuk menjamin pengakuan serta penghormatan atas hak 
dan kebebasan orang lain, dan untuk memenuhi tuntutan yang adil sesuai dengan pertimbangan moral, nilai-nilai agama, dan ketertiban umum.

Mengkaji pada Pasal 28A dan 28I ayat (1) UUD 1945 dinyatakan dengan tegas jika hak untuk hidup adalah hak asasi manusia yang tidak bisa dikurangi oleh siapapun dan dalam keadaan apapun. Tetapi pada konteks ini tidak boleh diartikan secara sepotong-sepotong saja pada Pasal 28A dan 28I ayat (1), namun harus diartikan secara keseluruhan dengan Pasal 28J ayat (2) yang menjadi batasannya. Batasan itu meliputi pengecualian, membatasi, mengurangi, dan bahkan menghilangkan hak yang dimaksud semata-mata untuk menjamin pengakuan serta penghormatan atas hak dan kebebasan orang lain, dan untuk memenuhi tuntutan yang adil sesuai dengan pertimbangan moral, nilai-nilai agama, dan ketertiban umum (Asnawi, 2012).

Dalam sudut pandang Undang-undang Nomor 39 Tahun 1999 tentang Hak Asasi Manusia yang mengatur hak untuk hidup ke dalam 2 pasal, yaitu Pasal 4 dan Pasal 9 meliputi:

a. Pasal 4: Hak untuk hidup, hak untuk tidak disiksa, hak kebebasan pribadi, pikiran dan hati nurani, hak beragama, hak untuk tidak diperbudak, hak untuk diakui sebagai pribadi dan persamaan di hadapan hukum, dan hak untuk tidak dituntut atas dasar hukum yang berlaku surut adalah hak asasi manusia yang tidak dapat dikurangi dalam keadaan apapun dan oleh siapapun.

b. Pasal 9: Setiap orang berhak untuk hidup, mempertahankan hidup, dan meningkatkan taraf kehidupannya.

Menelisik dalam Pasal 4 dan Pasal 9 Undang-Undang tersebut dapat disimpulkan bahwa penjatuhan pidana mati terhadap narapidana tidak bertentangan dengan Undangundang Nomor 39 Tahun 1999 tentang Hak Asasi Manusia. Dengan kata lain, bahwa hak asasi manusia yang dianut oleh bangsa Indonesia memang mengenal pembatasanpembatasan sebagaimana dimaksud dalam Tap MPR Nomor XVII/MPR/1998, Undangundang HAM, dan UUD 1945 khususnya Pasal 28J. Ini artinya bahwa ancaman pidana mati pada undang-undang atau aturan lain dapat dikatakan sudah mempunyai landasan konstitusional yang sah (Susanto \& Ramdan, 2017).

Menurut sudut pandang Universal Declaration on Human Rights 1948 yang merupakan pengakuan terhadap hak-hak asasi manusia mengklasifikasikan Prinsip-prinsip dalam Deklarasi HAM antara Iain:

a. pengakuan terhadap martabat dasar (inherent dignify) dan hak-hak yang sama dan sejajar (equal and inalienable rights) sebagai dasar dari kemerdekaan, keadilan dan perdamaian dunia;

b. membangun relasi yang baik antarbangsa;

c. perlindungan Hak Asasi Manusia sesuai rule of law;

d. persamaan antara laki-laki dengan perempuan; dan

e. kerjasama antara Negara dengan PBB untuk mencapai pengakuan universal terhadap HAM dan kebebasan dasar. 
Ketentuan-ketentuan yang ada pada Deklarasi Hak Asasi Manusia ini dianggap memiliki nilai sebagai hukum kebiasaan internasional (customary international law). Deklarasi Hak Asasi Manusia dibagi kedalam dua bagian, yakni Civil and Political Rights (ICCPR) and Economic and Social Rights (ICESCR).

Konvensi Internasional Hak Sipil dan Politik (ICCPR) tahun 1966 yang sudah diratifikasi oleh Indonesia menyatakan jika hak atas hidup adalah hak yang mendasar dan tidak dapat dilanggar dalam keadaan apapun (Hasan, 2005). Pengecualian hak untuk hidup oleh ICCPR terkait dengan pidana mati ada beberapa pasal yang mengaturnya, yakni Pasal 6 ayat (1) tidak melarang hukuman mati, tetapi Pasal 6 ayat (2) dan ayat (6) meletakkan sejumlah pembatasan dalam penerapannya. Lima pembatasan spesifik terhadap pidana mati dapat diidentifikasi dari ketentuan Pasal 6 ayat (2) dan Pasal 6 ayat (6), yaitu:

a. Pembatasan pertama, pidana mati tidak dapat diberlakukan kecuali pada kejahatan paling mengkhawatirkan dan sesuai dengan hukuman yang sah disaat tindakan kejahatan berlangsung. Jadi, meskipun Pasal 6 ICCPR tidak menghapuskan pidana mati, tetapi ia membatasi peranannya pada kejahatan dengan extremely grave consequences atau kategori kejahatan yang sangat serius dengan akibat buruk yang dahsyat.

b. Pembatasan kedua, hukuman mati dalam Pasal 6 ICCPR adalah kewajiban ketiadaan suatu perampasan kehidupan yang bertentangan dengan ketentuanketentuan kovenan, maka harus ada jaminan pemeriksaan yang adil, harus tidak ada diskriminasi dalam hukuman berat, dan metode eksekusi yang tidak sampai menjadi penyiksaan atau hukuman yang kejam, tidak manusiawi, atau merendahkan martabat.

c. Pembatasan ketiga, bahwa hukuman mati hanya bisa dilakukan sesuai dengan putusan akhir yang dijatuhkan oleh pengadilan yang berwenang.

d. Pembatasan keempat, bahwa siapa saja yang dihukum mati berhak meminta pengampunan atau keringanan hukuman dan bisa diberi amnesti, pengampunan atau keringanan hukum.

e. Pembatasan kelima ialah bahwa hukuman mati tidak bisa dikenakan pada remaja di bawah umur 18 tahun dan tidak bisa dilaksanakan pada wanita hamil;

Menurut Achmad Ali, terdapat dua sila yang sangat mendukung pemberlakuan pidana mati untuk kejahatan-kejahatan yang sangat serius, yakni sila Ketuhanan Yang Maha Esa dalam mana semua agama mengenal pidana mati dan sila Kemanusiaan yang Adil dan Beradab yang berarti harus ada keseimbangan dalam keadilan (balancing justice) dengan memperhatikan posisi korban kejahatan, jangan hanya memperhatikan penjahatnya. Selanjutnya dikatakan bahwa adalah keliru anggapan kaum anti pidana mati yang menganalogikan vonis pidana mati sama dengan pembunuhan, yang berarti sama saja dengan menganalogikan pidana penjara dengan penculikan atau hukuman denda disamakan dengan perampasan atau pencurian (Matagang, 2017). 
Pelaksanaan hukum tidak hanya sebatas fungsi perundang-undangannya saja, tetapi juga aktivitas birokrasi pelaksanaannya. Narapidana yang telah lanjut usia sendiri dalam pelaksanaan kegiatan pembinaan nya membutuhkan kekhususan diantaranya adalah lebih mengedepankan kegiatan pembinaan psikis dan mental para narapidana lanjut usia sehingga kegiatan pembinaan lebih ringan. Proses pendampingan rohani juga turut dilibatkan agar para terpidana lanjut usia yang notabene secara fisik telah memasuki usia senja diharapkan mampu membuat terpidana lanjut usia tersebut merasa tenang dan damai. Terlebih pada terpidana yang dihukum pidana mati.

Sehingga apabila dilakukan putusan mati terhadap narapidana yang telah lanjut usia akan ada banyak kemungkinan kegiatan pelaksanaan eksekusi nya tersebut tidak bisa dilakukan akibat adanya hambatan, bisa dari fisik maupun kesehatan terpidana tersebut.

\section{Kesimpulan}

Pada sudut pandang hak asasi manusia, hukuman mati kepada narapidana lanjut usia tidak berbenturan dengan sumber-sumber hukum nasional maupun internasional, misalnya dengan UUD 1945, UU No. 39 Th 1999 mengenai Hak Asasi Manusia, Universal Declaration on Human Rights 1948, serta International Covenant on Civil and Politica Rights 1966. Di dalam sumber-sumber tersebut dikatakan kalau hak untuk hidup dijamin namun terdapat pembatasan-pembatasan yang ditentukan oleh undang-undang. 


\section{BIBLIOGRAFI}

Asnawi, Habib Shulton. (2012). Hak Asasi Manusia Islam dan Barat: Studi Kritik Hukum Pidana Islam dan Hukuman Mati. Supremasi Hukum: Jurnal Kajian Ilmu Hukum, 1(1). Google Scholar

Eleanora, Fransiska Novita. (2012). Eksistensi Pidana Mati Dalam Perspektif Hukum Pidana. Majalah Ilmiah Widya. Google Scholar

Hakim, Fatwa Nurul, Kartono, Drajat Tri, \& Demartoto, Argyo. (n.d.). Power Relations Of Children Facing The Law In The Application Of Diversion. Google Scholar

Hasan, Muhardi. (2005). Hak Sipil dan Politik. Jurnal Demokrasi, 4(1). Google Scholar

Kelik Wardiono, S. H., Natangsa Surbakti, S. H., Rachma, Widi Famaliya, \& SH, M. H. (2020). Eksekusi Pidana Mati Tindak Pidana Narkotika. Muhammadiyah University Press. Google Scholar

Matagang, Tadius. (2017). Eksistensi Hukuman Mati Dalam Sistem Hukum Di Indonesia. LEX ET SOCIETATIS, 5(3). Google Scholar

Moeljatno, S. H. (2021). KUHP (Kitab undang-undang hukum pidana). Bumi Aksara. Google Scholar

Ohoiwutun, Y. A., Nugroho, Fiska Maulidian, Nanda, Bangkit Delly Satria, \& Manek, Emanuel Dimas. (2019). Pembunuhan dan Eksistensi Sanksi Tindakan: Menuju Reformulasi Pasal 44 KUHP. Google Scholar

Rukajat, Ajat. (2018). Pendekatan penelitian kuantitatif: quantitative research approach. Deepublish. Google Scholar

Saleh, Roeslan. (1978). Masalah Pidana Mati. Jakarta: Aksara Baru. Google Scholar

Soemitro, Ronny Hanitijo. (1990). Metodologi penelitian hukum dan jurimetri. Ghalia Indonesia, Jakarta, 167. Google Scholar

Sumanto, Atet. (2004). Kontradiksi Hukuman Mati Di Indonesia Dipandang Dari Aspek Hak Asasi Manusia, Agama Dan Para Ahli Hukum. Perspektif, 9(3), 192-215. Google Scholar

Susanto, Mei, \& Ramdan, Ajie. (2017). Kebijakan moderasi pidana mati. Jurnal Yudisial, 10(2), 193-215. Google Scholar

Susilo, R. (1995). Kitab Undang-Undang Hukum Pidana (KUHP). Bogor: Politelia. Google Scholar

Wahyuni, Foni Mega. (2020). Penegakan Hukum Persidangan Cepat Dalam Penyelesaian 
Penerapan Hukuman Mati Terhadap Narapidana Lanjut Usia Ditinjau Dari Hak Asasi

Manusia

Perkara Pelanggaran Lalu Lintas (Studi Di Satlantas Polrestabes Medan). Google Scholar

\section{First publication right:}

Jurnal Syntax Fusion: Jurnal Nasional Indonesia

This article is licensed under:

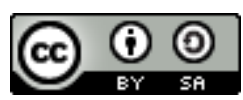

